\title{
Applications and Emerging Trends of Hyaluronic Acid in Tissue Engineering, as a Dermal Filler, and in Osteoarthritis Treatment
}

\author{
Amir Fakhari ${ }^{1}$ and Cory Berkland ${ }^{1,2,3,}{ }^{*}$ \\ ${ }^{1}$ Bioengineering Graduate Program, University of Kansas \\ ${ }^{2}$ Department of Pharmaceutical Chemistry, School of Pharmacy, University of Kansas \\ ${ }^{3}$ Departemant of Chemical and Petroleum Engineering, University of Kansas
}

\begin{abstract}
Hyaluronic acid (HA) is a naturally occurring biodegradable polymer with a variety of applications in medicine including scaffolding for tissue engineering, dermatological fillers, and viscosupplementation for osteoarthritis treatment. HA is available in most connective tissues in body fluids such as synovial fluid and the vitreous humor of the eye. HA is responsible for several structural properties of tissues as a component of extracellular matrix (ECM) and is involved in cellular signaling. Degradation of HA is a step-wise process that can occur via enzymatic or nonenzymatic reactions. A reduction in HA mass or molecular weight via degradation or slowing of synthesis affects physical and chemical properties such as tissue volume, viscosity, and elasticity. This review addresses the distribution, turnover, and tissue-specific properties of HA. This information is used as context for considering recent products and strategies for modifying the viscoelastic properties of HA in tissue engineering, as a dermal filler, and in osteoarthritis treatment.
\end{abstract}

\section{Keywords}

hyaluronic acid; crosslinking; dermal filler; viscosupplement

\section{Introduction to hyaluronic acid}

Hyaluronic acid (HA), also named hyaluronan, is a high molecular weight $\left(10^{5}-10^{7} \mathrm{Da}\right)$ naturally occurring biodegradable polymer. HA is an unbranched non-sulfated glycosaminoglycan (GAG) composed of repeating disaccharides ( $\beta$-1,4-D-glucuronic acid (known as uronic acid) and $\beta-1,3-N$-acetyl- $D$-glucosamide) (Figure 1) [1-3]. HA can include several thousand sugar molecules in the backbone. HA is a polyanion that can selfassociate and that can also bind to water molecules (when not bound to other molecules) giving it a stiff, viscous quality similar to gelatin [4].

Hyaluronic acid is one of the major elements in the extracellular matrix (ECM) of vertebrate tissues. It is available in almost all body fluids and tissues, such as the synovial fluid, the

\footnotetext{
(C) 2013 Acta Materialia Inc. Published by Elsevier Ltd. All rights reserved

*To whom correspondence should be addressed. 2030 Becker Drive Lawrence, KS 66047 Phone: (785) 864-1455 Fax: (785) 864-1454 berkland@ku.edu.

Publisher's Disclaimer: This is a PDF file of an unedited manuscript that has been accepted for publication. As a service to our customers we are providing this early version of the manuscript. The manuscript will undergo copyediting, typesetting, and review of the resulting proof before it is published in its final citable form. Please note that during the production process errors may be discovered which could affect the content, and all legal disclaimers that apply to the journal pertain.
} 
vitreous humor of the eye, and hyaline cartilage (Table 1) [5-8]. This biopolymer functions as a scaffold, binding other matrix molecules including aggrecan [2]. It is also involved in several important biological functions, such as regulation of cell adhesion and cell motility, manipulation of cell differentiation and proliferation, and providing mechanical properties to tissues [6]. Several cell surface receptors such as CD44, RHAMM, and ICAM-1 have been shown to interact with HA influencing cellular processes including morphogenesis, wound repair, inflammation, and metastasis [9-12]. Moreover, HA is responsible for providing the viscoelasticity of some biological fluids (synovial fluid and vitreous humor of the eye) and controlling tissue hydration and water transport (Table 1) [4]. In addition, HA has been found during embryonic development in the umbilical cord, suggesting materials composed of HA may persuade favorable conditions for tissue regeneration and growth [13-17].

HA's characteristics including its consistency, biocompatibility, and hydrophilicity have made it an excellent moisturizer in cosmetic dermatology and skin-care products [4]. Moreover, its unique viscoelasticity and limited immunogenicity have led to its use in several biomedical applications such as viscosupplementation in osteoarthritis treatment, as an aid in eye surgery, and for wound regeneration $[4,5]$. In addition, HA has currently been explored as a drug delivery agent for different routes such as nasal, oral, pulmonary, ophthalmic, topical, and parenteral [4, 18-22].

\section{History of hyaluronic acid}

In 1934, Karl Meyer and his colleague John Palmer were the first investigators who discovered and isolated HA from the vitreous body of cows' eyes [2, 4]. In the 1950s, the chemical structure of HA was solved by this group. They found that HA is composed of two sugar molecules ( $D$-glucuronic acid (known as uronic acid) and $D$ - $N$-acetyl glucosamine) and called it hyaluronic acid (hyaluronan). This name is derived from "hyalos" (the Greek word for glass + uronic acid). Initially, they isolated HA as an acid but it behaved like a salt in physiological conditions (sodium hyaluronate) $[2,4,5]$. Several years after them in 1942, Ender Balazs patented the first application of HA as a substitute for egg white in bakery products [4].

The first biomedical application of HA took place in late 1950s when HA was used for a vitreous substitution/replacement during eye surgery. For medical applications, HA was initially isolated from umbilical cords and shortly afterward, from rooster combs [4, 5]. Later on, HA was isolated from other sources and the structural/biological characteristics of this polysaccharide were investigated more deeply in several laboratories [4].

\section{Properties of hyaluronic acid}

\subsection{Chemical properties of hyaluronic acid}

Structural studies showed that the two sugar molecules, $D$-glucuronic acid and $D$ - $N$-acetyl glucosamine, in the HA disaccharide structure are connected together through alternative $\beta-1,4$ and $\beta-1,3$ glycosidic bonds (Figure 1) [2, 4]. The hyaluronic acid backbone is stiffened in physiological solution via a combination of internal hydrogen bonds, interactions with solvents, and the chemical structure of the disaccharide. HA molecular investigations suggested that the axial hydrogen atoms form a non-polar face (relatively hydrophobic) and the equatorial side chains form a more polar face (hydrophilic) which led to a twisted ribbon structure for HA called a coiled structure [4].

HA's structural characteristics hinge on this random coiled structure in solution. At very low concentrations, chains entangle each other, leading to a mild viscosity (molecular weight dependent). On the other hand, HA solutions at higher concentrations have a higher than 
expected viscosity due to greater HA chain entanglement that is shear-dependent. For instance, a $1 \%$ solution of high molecular weight $\mathrm{HA}(\mathrm{Mw}>\sim 1000 \mathrm{kDa}$ ) can behave like jelly, but when shear stress is applied it will easily shear thin and can be injected via a thin needle [4]. As such, HA is known as a "pseudo-plastic" material. This rheological property (concentration and molecular weight dependent) of HA solutions has made HA ideal for lubrication in biomedical applications [4].

In addition to the unique viscosity of HA, the viscoelasticity of HA is another characteristic resulting from entanglement and self-association of HA random coils in solution [2]. It was suggested that the molecular self-association of HA occurs by forming anti-parallel double helices, bundles and ropes. Further experiments verified that HA chain-chain association indeed occurred in solution. Moreover, studies proposed that hydrogen bonding between adjacent saccharides occurred alongside mutual electrostatic repulsion between carboxyl groups, thus stiffening HA networks [4, 7, 23]. Viscoelasticity of HA can be tied to these molecular interactions which are also dependent on concentration and molecular weight.

Electrostatic and ionic effects on HA have also been evaluated as a function of counter-ion type and valency. Studies suggested that these greatly affect rheological and hydrodynamic properties of HA. In one study, the effect of electrostatic and ionic interactions was investigated by comparing HA solution properties in deionized water (D.I.), $0.5 \mathrm{M} \mathrm{NaCl}$, and $0.5 \mathrm{M} \mathrm{NaOH}$. The role of hydrogen bonds was investigated by comparing concentration-dependent solution properties. This revealed the effect of electrostatic shielding and also the profound effect of alkaline $\mathrm{pH}$ on HA chain stiffness. The study also showed that solution properties affect the hydrogen bonding and electrostatic interaction between the solution and HA resulting in a change in HA chain stiffness [2, 24]. Moreover, the hydrodynamic radius of HA was found to be greater in D.I. water than in $0.5 \mathrm{M} \mathrm{NaCl}$ or $0.5 \mathrm{M} \mathrm{NaOH}$ (D.I. water $>0.5 \mathrm{M} \mathrm{NaCl}>0.5 \mathrm{M} \mathrm{NaOH}$ ). The high $\mathrm{pH}$ shrank the volume occupied by HA (i.e. the apparent size of the polymer chains). The volume occupied by HA chains was decreased by more than 100 times when changing from D.I. water to $0.5 \mathrm{M}$ $\mathrm{NaOH}$. This dramatic change was attributed to increased electrostatic interactions and hydrogen bond formation resulting in the reduction of the hydrodynamic radius of HA [2].

\subsection{Biological properties of hyaluronic acid}

As mentioned before, hyaluronic acid performs several structural tasks in the extracellular matrix (ECM) as it binds with cells and other biological components through specific and non-specific interactions. Several extracellular matrix proteins are stabilized upon binding to HA. Specific molecules and receptors that interact with HA are involved in cellular signal transduction; molecules such as aggrecan, versican, and neurocan, and receptors including CD44, RHAMM, TSG6, GHAP, ICAM-1 and LYVE-1 are examples of cell components that bind to HA [4]. Between these receptors, CD44 (cell surface glycoprotein) and RHAMM (receptor for HA-mediated motility) seem to have received more attention since they have been found to be involved in cancer metastases [25-27]. CD44 is a structurally variable and multifunctional cell surface glycoprotein on most cell types and is perhaps the best characterized transmembrane HA receptor so far. Due to its wide distribution and based on current knowledge, CD44 is currently considered to be the primary HA receptor on most cell types [28].

New receptors for HA have been identified recently and the function of some HA receptors have recently been described. RHAMM has been found on surface of the cells, as well as in the cytosol and nucleus. It regulates cellular responses to growth factors and plays a role in cell migration, particularly for fibroblasts and smooth cells [4, 29, 30]. TSG6, a $35 \mathrm{kDa}$ glycoprotein with a link module in the N-terminus, has also been reported to bind with HA [31]. GHAP (glial hyaluronate-binding protein) is a naturally occurring versican degradation 
product which forms a fine net surrounding myelinated optic nerve axons, although no or only faint staining of GHAP is noticed in the optic nerve head. GHAP could also bind to HA. It one study, HA and GHAP vanished from optic chiasm and contralateral optic nerves treated with hyaluronidase [32, 33].

ICAM-1 (intracellular adhesion molecule-1) has been reported as an active cell surface receptor for HA. According to the literature, this protein is responsible for removing HA from lymph and blood plasma, which likely encompasses most of the HA turnover. HA binds to ICAM-1 expressed on lymphocytes and endothelial cells [34]. In the urothelium, HA inhibits adherence of immune complexes to polymorphonuclear cells [34]. It also prevents leukocyte migration and aggregation[34]. Another study showed that binding HA to ICAM-1 does not induce endocytosis, which further complicates the role of ICAM-1 as a receptor for HA [35].

LYVE-1 (lymphatic vessel endothelial HA receptor) is related close to CD44. LYVE-1 is preferentially available on lymphatic endothelial cells that do not express CD44 [36]. In addition, LYVE-1 is available in the sinusoidal endothelium of liver and spleen and is expressed in discrete populations of activated macrophages. It has been shown that HA endocytosis is mediated by LYVE-1 in transfected fibroblasts [37-39]. It is also shown that LYVE-1 has a significant regulatory function in the catabolism of HA in the aforementioned organs and a role in HA signaling or cellular migration and differentiation [2, 38].

Toll-like receptors (TLRs) are a group of receptors which are members of the interleukin-1 receptor family. TLR-4 is widely available in tissues, including liver, brain, heart, and kidney [40, 41]. TLRs work as activator for monocytes, macrophages and dendritic cells, and therefore act as initiator for defending against bacterial infection [42-45]. Tetra and hexasaccharides (low molecular weight HA) but not intermediate or high molecular weight HA (80,000-600,000 kDa) binds to TLR-4 (e.g. mature dendritic cells) [46]. Upon inflammation and tissue injury, high molecular weight HA in extracellular matrix is broken down into lower molecular weight HA fragments, which can activate an innate immune response. This activation was reported to result from the binding of low molecular weight HA fragments to TLR-2 and/or TLR-4 receptors [47, 48].

Hyaluronic acid also stimulates gene expression in macrophages, endothelial cells, eosinophils, and certain epithelial cells. High molecular weight HA does not seem to be involved in gene expression and only low/intermediate molecular weight HA $\left(2 \times 10^{4}-4.5 \times 10^{5} \mathrm{Da}\right)$ is known to promote gene expression $[4,46,49]$. As an example, HA is known to have an important role in wound healing and scar formation. Products of HA degradation (low molecular weight HA) were found to contribute to the scar formation process. Moreover, scar formation was minimized when high molecular weight HA was found in wound fluid during fetal wound healing. These results suggested that the molecular weight of HA plays a significant role in wound healing and scar formation. The findings also suggested that high molecular weight HA favored cell quiescence and supported tissue integrity, whereas production of HA fragments signaled injury and initiated the inflammatory response $[2,4,50]$.

HA can be a key player in the activation or suppression of inflammation. Over the early steps of inflammation, HA participates in the improvement of cell infiltration [51]. It facilitates an increase in pro-inflammatory cytokines TNF-a, IL-1b and IL-8 through a CD44-mediated mechanism [52]. The inflammatory response can also be propagated by releasing TSG-6, an HA binding protein, which is simulated by TNF-a [53, 54]. HA also affects the adhesion of cytokine-activated lymphocytes to the endothelium [55]. The free radical scavenging and antioxidant characteristics of HA influence suppression of the 
inflammatory response $[46,56]$. In addition, HA may also operate as a negative feedback loop in inflammatory activation.

Cell proliferation is an important phase of the tissue repair process after damage (e.g. by inflammation) [54]. HA is necessary for fibroblast detachment from the extracellular matrix and mitosis $[57,58]$. HA has a mitogenic influence directly on cells however the relief of detachment permits mitosis to take place and therefore HA has a function in cell proliferation indirectly [59]. In the early stages of wound repair when increased HA synthesis takes place, cell migration is promoted [60-64]. The newly deposited ECM rich in HA provides an open, hydrated environment that aids cell migration via CD44 and RHAMM [2, 65-69].

The key element of wound repair is angiogenesis. The angiogenic characteristics of low molecular weight HA oligosaccharides have been explained in detail elsewhere [2, 46, 7078]. When ECM forms, the peripheral keratinocytes undergo an increase in mitosis and proliferation before migration across the new matrix. The matrix, rich in HA, supports and develops the proliferating basal keratinocytes and aids their movement via a CD44-mediated mechanism [79-83]. After re-epithelialization has taken place, remodeling occurs for the new matrix [84]. The remodeling process can lead to scarring. Matrix rich in HA observed in fetal wounds suggests that HA may decrease collagen deposition, thereby improving remodeling and decreasing scarring $[2,85,86]$.

\section{Synthesis of hyaluronic acid}

Hyaluronic acid is a natural polymer biologically synthesized by cells in the body via an enzymatic process. HA production is a unique, highly controlled, and continuous process, HA is produced and secreted by cells including fibroblasts, keratinocytes, or chondrocytes. The Golgi network is the production site for most glycosaminoglycans. In tissues such as skin and cartilage where HA comprises a large portion of the tissue mass, the level of HA synthesis is very high. HA is naturally synthesized by hyaluronan synthases (HAS1, HAS2, and HAS3), a class of integral membrane proteins $[4,87,88]$. In HA production by hyaluronan synthase enzymes, large linear polymers of the repeating disaccharide units are made. The mechanism of HA synthesis involves chain extension by addition of a monosaccharide (alternating addition of glucuronic acid and $N$-acetyl glucosamine) to the reducing end of the chain $[2,4,10]$. The number of repeat disaccharides in a completed HA molecule can reach as high as 10,000 or more and a molecular weight of around 4 million Daltons (molecular weight of each disaccharide is about 400 Daltons). Since the average length of a disaccharide is about $1 \mathrm{~nm}$, a HA molecule of 10,000 repeats could extend 10 $\mu \mathrm{m}$ if stretched from end to end (approximately equal to the diameter of a human erythrocyte) $[4,10,89,90]$.

\section{Degradation of hyaluronic acid}

Degradation of HA is a step-wise process that can occur via enzymatic or non-enzymatic reactions. Three types of enzymes (hyaluronidase, $\beta$ - $D$-glucuronidase, and $\beta$ - $N$-acetylhexosaminidase) are involved in enzymatic degradation of hyaluronic acid. These enzymes are found in various forms, in the intercellular space and in serum. Hyaluronidase cleaves high molecular weight HA into smaller fragments while the other two enzymes degrade the fragments by removing non-reducing terminal sugars [4, 91, 92]. It was observed that cleavage can occur in a single glycosidic bond on the HA backbone causing fragmentation or the enzyme can remove a single monosaccharide unit from the HA backbone [91]. Enzymes not only help to degrade HA but also play an important role defining HA. For instance, enzymes available in the cytosol of cells are involved in the trimming of oligosaccharides [91]. 
Non-enzymatic mechanisms of HA degradation include thermal or shear stress. Ultrasonication degrades HA in a non-random fashion. Studies suggested that high molecular weight HA chains degraded slower than low molecular weight HA chains subjected to ultrasonication $[2,91]$. Heat is another type of stress leading to HA degradation. Rheological studies on HA solutions showed that increasing temperature resulted in degradation and decreased viscosity exponentially as a function of temperature [91].

In addition, chemical reactions such as acidic/alkaline hydrolysis and degradation by oxidants are categorized as non-enzymatic degradation pathways for HA [91-93]. These types of degradation occur in a random fashion often resulting in disaccharide fragment production. Acidic hydrolysis degrades the glucuronic acid moiety. On the other hand, alkaline hydrolysis occurs on $N$-acetylglucosamine units [91]. HA can also degrade via oxidation. Reactive oxygen species (ROS) can be generated from cells as a consequence of aerobic respiration. Superoxide anions, hydroxyl radicals, and hypochloride are examples of species that cause HA chain cleavage. ROS are proposed to be involved in several inflammatory and degenerative processes such as arthritis but their mechanism of action in the disease are myriad and still largely defined $[2,91]$.

\section{Turnover and possible pathways for elimination of hyaluronic acid}

Studies showed that the concentration of HA in the human body varies from a high concentration of $4 \mathrm{~g} / \mathrm{kg}$ in umbilical cord, $2-4 \mathrm{~g} / \mathrm{L}$ in synovial fluid, $0.2 \mathrm{~g} / \mathrm{kg}$ in dermis, and about $10 \mathrm{mg} / \mathrm{L}$ in thoracic lymph, to a low concentration of $0.1-0.01 \mathrm{mg} / \mathrm{L}$ in normal serum.

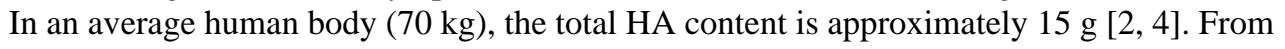
this $15 \mathrm{~g}$, the largest amount was found in the extracellular matrix (ECM) of skin and musculoskeletal tissue. Depending on the location in the body, most of the HA is catabolized within days. Studies indicated that the normal half-life of HA varied from 1-3 weeks in inert tissues such as cartilage to 1-2 days in the epidermis of skin. The half-life in blood was much shorter (2-5 minutes). Besides the enzymatic degradation and nonenzymatic degradation pathways described previously, two more pathways are engaged in HA catabolism: turnover (internalization and degradation within tissue) and release from the tissue matrix, drainage into the vasculature, and clearance via lymph nodes, liver, and kidney (Figure 2) [2].

In structural tissues like bone or cartilage with no or little lymphatic drainage, HA degradation occurs in situ with other ECM molecules such as collagens and proteoglycans. On the other hand, in skin and joints, a minimal fraction (approximately 20-30\%) of HA degrades in situ. Approximately, 50\% of HA in the body is available in skin tissue. Since HA is restricted to the small intracellular space of skin tissue, its half-life is a bit longer at days to weeks [2, 92]. Usually, the HYAL enzymes (hyaluronidases) are assumed to be the predominant catabolic mechanism involved in this process throughout the vertebrate body. However, HA catabolism can take place by either enzymatic degradation or scission by reactive oxygen species (ROS). Both mechanisms take place at the same time, but the relative contribution is unclear [92].

Hyaluronidases are an enzyme protein family with a high degree of sequence homology. There are six genes tightly clustered at two chromosomal locations. Three genes encode for HYAL1, HYAL2, and HYAL3 hyaloronidases. HYAL1 and HYAL2 form the major hyadonidases of somatic tissues. HYAL2, which is fixed to plasma membrane, cleaves high molecular weight HA to a product of approximately $20 \mathrm{kDa}$. HYAL1 seems to be a lysosomal enzyme, cleaving HA mainly into tetrasaccharides. HYAL3 is broadly expressed however its function is not well understood. Three additional genes encode for HYAL4, PHYAL1 (pseudogene HYAL1), and SPAM1 (Sperm Adhesion Molecule-1) 
hyaluronidases. The mechanisms of action for these three hyaluronidases are still unknown [94].

HA can also be eliminated through the lymphatic system draining the extracellular space of relatively dense tissues. First, high molecular weight HA is partially degraded before it releases from the tissue matrix. Upon release from the tissue matrix, degraded HA enters the lymphatic system. HA metabolic degradation mostly takes place in the lymphatic system as HA drains through peripheral tissues to the blood circulation [2]. One of the functions of the lymphatic system is to collect filtered plasma and interstitial fluid and transport them back to the blood circulation. Studies showed that most of the subcutaneously injected radio-labeled HA is picked up and degraded in lymphatic tissue [2, 92]. Remaining HA enters into the blood circulation and is rapidly removed in the liver by sinusoidal endothelial cells or eliminated via kidneys. In the blood circulation, the liver eliminates about $80 \%$ of HA and kidneys clear $10 \%$ of HA from bloodstream (Figure 2). As mentioned before, the daily turnover of HA is on the order of one-third (5 g) of the total HA body content (15 g) [2].

Synovial fluid is one of the body fluids containing high molecular weight HA. Lubrication and viscoelasticity are provided by the high molecular weight HA in synovial fluid. In a healthy joint, high levels (2-4 g/L) of HA with high molecular weight (approximately 6-7 $\mathrm{MDa}$ ) are required for synovial fluid to function properly. In order to maintain synovial fluid lubrication and viscoelasticity, macromolecules including HA are continuously secreted by synoviocytes into the synovial fluid. Every time pressure is increased, fluid is pushed out of the joint cavity into micro-capillaries embedded in the synovium. Therefore, HA escapes through the interstitial drainage pores in the synovial lining (diameter 30-90 nm). It is also suggested that high molecular weight HA can form a layer at the tissue-fluid interface forming a "shell" that is not drained into micro-capillaries. The normal intra-articular turnover time for HA was found to be less than 40 hours. Studies showed that both HA molecular weight and concentration are decreased in patients with arthritis resulting in a significant reduction in synovial fluid functionality. Moreover, studies showed that production and secretion of ROS in arthritic joints degraded the HA in synovial fluid and cartilage [2, 4, 95-97].

\section{Biomedical application of hyaluronic acid}

\subsection{Application of hyaluronic acid in tissue engineering}

Since hyaluronic acid is one of the main components of body tissues, its potential for tissue engineering applications has been highly touted. HA is highly soluble at room temperature and has a high rate of elimination and turnover depending on its molecular weight and location in the body. Each of these properties could be a barrier for HA scaffold fabrication and structural integrity. To overcome these limitations, modification and crosslinking of hyaluronic acid have been proposed $[5,98,99]$. To chemically modify HA, thee functional groups of HA (the carboxylic acid, the primary and secondary hydroxyl groups, and the $\mathrm{N}$ acetyl group) have been targeted. All of these HA modifications have been divided into two categories: "monolithic" and "living" [18]. Monolithic terminally-modified HA derivatives cannot be used for crosslinking in the presence of live cells or tissues. Living HA derivatives, however, can be used for crosslinking and covalent bond formation in the presence of cells. Living HA derivatives are needed in most cases for clinical and preclinical applications in 3D cell cultures and cell delivery in vivo. This topic has been thoroughly addressed elsewhere [18], but key highlights are offered below.

Currently, water-soluble carbodiimide crosslinking [100], polyvalent hyadrazide crosslinking [101], divinyl sulfone crosslinking [102], disulfide crosslinking [56], and photocrosslinking of hydrogels through glycidyl methacrylate-HA conjugation [103] have 
been introduced for tissue engineering applications of HA. Chemical crosslinking of HA combines desirable biological and mechanical properties, even for bone or cartilage tissue engineering $[5,98]$. Moreover, crosslinking extends the HA degradation process in vivo and provides long-term stability. Crosslinking HA at various densities has been used for multiple applications including orthopedics, cardiovascular medicine, and dermatology [98].

Common functional groups used for radical polymerization are acrylates and methacrylates because these functional groups immediately react with radicals generated during photopolymerization. Carboxyls on the HA backbone are functional groups often used for modifications to introduce methacrylates. The reaction of glycidyl methacrylate with HA to create GMHA conjugates is another approach for HA functionalization and photocrosslinking. Crosslinking of GMHA macromers into hydrogels facilitated the production of a range of degradation and material characteristics [18, 103]. Photocrosslinking produced dense and strong gels. In addition, a range of complex fluids (microgels) were developed using low degrees of crosslinking. GMHA hydrogels were also copolymerized with acrylated versions of poly(ethylene glycol) (PEG) and PEG-peptide macromers [104]. Moreover, IPNs of the GMHA and N-dimethylacrylamide have also been produced to develop high moduli hydrogels. These gels were shown to be biocompatible, however, encapsulation in these high modulus gels has not been achieved before $[18,105-$ 107]. Photopolymerization has also been performed by grafting poly(2-hydroxyethyl methacrylate) or cinnamic acid to HA [18, 108, 109].

Photocrosslinked HA hydrogels have been shown to be used for different applications including cartilage tissue engineering, cardiac repair, molecule delivery, valvular engineering, control of stem cell behavior, and microdevices [18]. Studies have suggested positive results for cell growth on photocrosslinked HA networks incorporated with chondrocytes. Chondrocytes within the HA hydrogel retained viability and were able to generate cartilage within the porous network $[98,110]$. This type of photopolymerization has also been used in heart valve applications to mimic cardiac valve development [25]. In another study, IPNs of collagen within an HA hydrogel were developed with advantages of both mechanical stability of photocrosslinked HA networks and cellular adhesion to collagen $[18,111]$.

Several studies have reported the encapsulation of mesenchymal stem cells (MSCs) or chondrocytes into this type of HA hydrogels to regenerate damaged cartilage tissue. A novel study extended the advantage of redox-initiated HA hydrogels to cardiac repair [112]. Photocrosslinked HA is also being studied for valvular engineering due to the presence of HA within the structure of the native valve. Studies showed that valvular interstitial cells (VICs) are not easy to culture in ordinary culture mediums with peptide- and proteinmodified surfaces but these cells adhered to and proliferated on HA hydrogels [18, 113]. Moreover, photocrosslinked HA was suggested for use in 3D stem cell encapsulation to regulate the differentiation of trapped stem cells. For example, HA hydrogels have been introduced into microbioreactor systems which allow for the 3D cultivation of hESCs [18, $114]$.

HA has also been combined with other polymers such as polypyrrole to develop multifunctional copolymers. HA functionalized with polypyrrole is electronically conductive and supports cell growth. This copolymer could offer unique properties for tissue engineering applications $[115,116]$. In one study, $\mathrm{N}$-(1-aminoprop-3-yl) pyrrole was conjugated with HA using carbodiimide chemistry. Then, PyHA was electrochemically polymerized to form a stable, biocompatible $20-40 \mathrm{~nm}$ HA coating on conducting polymer substrates including indium tin oxide, platinum, and polystyrene sulfonate-doped polypyrrole surfaces. These covered surfaces were hydrophilic and resistant to fibroblast and 
astrocyte attachment. The immobilized HA films were stable under physiological conditions for three months $[18,117]$.

Benzyl derivatives of HA are another category of polymeric scaffolds used for tissue engineering of cartilage to modulate degradation rates. Studies on these derivatives suggested the potential of benzyl esters of HA as a scaffold for chondrocytes in cartilage tissue engineering. These scaffolds are hydrophobic and degrade at predictable rates. In an early study, implanting one of these cell-seeded scaffolds in mice showed development of cartilage. In a recent human clinical study, the benzyl HA scaffold was used for cartilage regeneration. After implantation of the scaffold, the graft had integrated with surrounding cartilage and developed "normal"-looking tissue in the damaged area. Another study showed evidence of chondrocyte differentiation, collagen type II and aggrecan production, and an overall down regulation of collagen type I using this type of scaffold. Similar studies conducted with rat mesenchymal stem cells (MSCs) loaded into benzyl HA grafts suggested that the implants exhibited properties conducive to both chondrocyte differentiation as well as the formation of fibrocartilaginous tissue in vivo $[98,118]$.

Since HA is a biocompatible natural polymer, development of scaffolds based on HA appears to be suitable for surfaces contacting blood. For example, HA crosslinked with divinyl sulfone (DVS) in the presence of ultraviolet light has been suggested as a "nonactivating" surface for cell adhesion in heart valve tissue engineering. In one study a DVScrosslinked HA scaffold was seeded with smooth muscle cells. This research showed that smooth muscle cells increased the synthesis of elastin and collagen, essential components of aortic valve tissues, compared to cells cultured on plastic culture plates [88, 98, 119].

To synthesize artificial extracellular matrices (ECMs) for regenerative medicine applications, modification of glycosaminoglycans (GAGs) including HA has also been reported [18]. For this purpose, thiol modification of the HA carboxylate groups has been reported in a research study. Thiol-modified HA forms a biocompatible hydrogel spontaneously via self-crosslinking when exposed to the air. Crosslinking with difunctional electrophiles is possible in the presence or absence of cells $[18,120,121]$. The first preclinical application of crosslinked thiolated HA and gelatin was explored for mesenchymal stem cell delivery to full-thickness defects in the patellar groove of rabbit femoral articular cartilage. The defects totally healed after 12 weeks [18]. In another study, HA was modified via bromoacetate (haloacetate-modified HA) to form a hydrogel. Similar to thiol-modified HA, this modification resulted in a biocompatible hydrogel that could be used for tissue regeneration. Cells failed to proliferate on the scaffold unless gelatin was added, suggesting attachment and visibility on the gelatin-containing scaffolds [18, 122].

Hydrazide modification using adipic dihydrazide has also been employed to develop HA derivatives. Dihyadrazide-modified HA are able to form hydrazine linkages with ketones and aldehydes as well as acylhydrazides with acylating agents, thus allowing crosslinking and hydrogel formation or conjugation of drugs or polypeptides to HA backbone [18, 123]. Other techniques including tyramine modification of HA, aldehyde modification of HA, and huisgen cycloaddition (click chemistry) have also been introduced to produce HA hydrogels for cell delivery and to simulate ECM in regenerative medicine [18, 124-126].

Auto-crosslinked and in situ crosslinked HA hydrogels are another category of crosslinking used for tissue engineering. The requirement for surgical implantation is the major limitation of most scaffolds used for tissue engineering. Application of HA that crosslinks after injection has been introduced for three main reasons. First, the injectable HA could be filled into defects of any shape and crosslinked in situ. Second, crosslinkable HA may adhere to the native tissue resulting in mechanical or chemical interlocking and a cohesive scaffold- 
tissue interface. Third, injection and laparoscopic methods can be used to reduce the invasiveness of the surgical procedure [127]. Studies showed that HA crosslinked using adipic acid dihydrazide and aldehyde chemistry could form a flexible hydrogel in situ upon mixing [128]. In another study, poly(lactic-coglycolic acid) nanoparticles were mixed with HA of similar chemistry to develop an in situ crosslinkable system with drug delivery potential. Although such in situ crosslinking has been shown to form flexible hydrogels with reasonable mechanical properties, potential cytotoxicity of the reactions used in these techniques are still an important issue to consider [129].

In all of the described techniques, chemical reactions have been used to either modify the HA backbone or to crosslink HA for hydrogel formation. In most cases, the proposed crosslinking chemical reaction and/or reagents used have still shown cytotoxicity. In the case of HA backbone functionalization, pre-crosslinking modifications require an additional step to hydrogel formation which can make the overall scaffold fabrication more complex. Therefore, there is a demand for in situ crosslinking strategies to develop simple techniques free of chemical reactions for HA based scaffold fabrication with low or no toxicity issues.

\subsection{Application of hyaluronic acid as a dermal filler}

The influence of sun exposure, gravity, and years of facial muscle movements starts to appear as wrinkles on the skin. During the aging process, basic changes in the skin, soft tissue, and skeletal support of the face occur resulting in a breakdown of the tissues under the skin leaving lines or other facial defects [130,131]. Skin aging can be divided in two categories: internal aging and external aging.

Internal aging of skin causes various histological changes in different skin layers such as flattening of the epidermal-dermal interface, a decrease in the number of melanocytes and Langerhans cells in the epidermis, a loss of dermal papillae, dermal atrophy, a decrease in the number of mast cells, fibroblasts, and blood vessels, a loss of elastic tissue in the fine subepidermal elaunin network, and abnormal thickening and fragmentation of elastic tissue in the reticular dermis [131]. Internal aging also reduces several skin functions such as type I and type III collagen production, the epidermal turnover rate, and melanocyte activity [131, $132]$.

External aging is influenced by sun exposure and UV radiation and also causes histological changes which are different from some of the changes caused by internal aging. External aging is typified by damage of elastic tissue and decrease in cellularity. Photodamage induces elastosis, the overgrowth of abnormal elastic fibers, and an increase in population of histiocytes, fibroblasts, and mast cells [131, 132]. In both internal and external aging, collagen content and melanocyte activity are decreased and wound healing is abnormal [131].

To address age-related changes in skin quality and appearance, several treatments have been proposed (Table 2). Development of soft-tissue fillers (dermal fillers) can help lines and wrinkles to be filled temporarily (or 'permanently') [130]. It seems an ideal dermal filler should be temporary but long-lasting (months to a year or longer), having minimum side effects and no allergenic effect, easy to administer, having minimum pain or no pain upon injection, and a reasonable cost for both the physician and the patient [130]. Depending on the residence time in tissue, dermal fillers are categorized as temporary, semipermanent (at least 18 months), and permanent. They are also classified based on their composition with primary ingredients such as collagen (bovine, porcine, or human), animal or synthetic hyaluronic acid, poly-L-lactic acid, calcium hydroxyapatite, polymethyl methacrylate, and polyacrylamide gel (Table 3$)[3,131,133,134]$. 
Hyaluronic acid has been approved by the Food and Drug Administration (FDA) as a dermal filler. In 2006, cosmetic injections of HA were known to be the second most popular nonsurgical procedure for women and the third most popular procedure for men [135-138]. HA has a very short half-life and, therefore, is chemically crosslinked to extend duration as a dermal filler [139]. HA is not involved in the structure of collagen and does not enhance the shortage of HA in aged skin, but simply works by augmenting volume [130, 135].

A set of chemical modifications are required to apply to HA as a dermal filler. HA employed to make dermal fillers is usually provided to the manufacturer in a dry powder form. Combining this powder with water forms a viscous solution of HA. This solution is known as free HA, which is uncrosslinked and unmodified. If this product was to be used as a dermal filler, it would be rapidly eliminated from the injection site by drainage or degradation pathways (less than a week). To overcome the lack of residence of HA solutions, dermal fillers were developed using crosslinked HA. The crosslinking creates a polymer network, transforming a viscous solution to a weak gel. HA gel imparts a physical and chemical barrier to deter drainage or degradation. Therefore, residence time increases by crosslinking HA [130].

The two crosslinkers employed in HA dermal fillers currently on the US market are 1,4butanediol diglycidal ether (BDDE), and divinyl sulfone (DVS). Both of them react to hydroxyl groups on HA chains and give similar outcomes; slowing down the drainage and degradation of dermal fillers injected into the skin [130]. In the US, collagen-based fillers were used by physicians for the treatment of lines and wrinkles through the 1980s and the 1990s. In Europe, however, dermal fillers were developed that would soon influence the majority of US doctors to use fillers for their patents. This revolution started with the development of HA fillers [136].

Since its launch in Europe in 1996, HA has become the "gold standard" in fillers for treating wrinkles, hydrating skin, and increasing volume [3]. Many dermal fillers have been developed since that time. Restylane ${ }^{\circ}$, Perlane ${ }^{\circledR}$ (FDA approved), and Sub-Q ${ }^{\circledR}$ (not FDA approved) from Q-Med AB (Upsala, Sweden) is made from HA beads within a solution of HA. Hylaform ${ }^{\circledR}$, Captique $^{\mathrm{TM}}$, Juvéderm ${ }^{\mathrm{TM}}$ (FDA approved), Surgiderm ${ }^{\circledR}$ (not FDA approved), and Voluma ${ }^{\circledR}$ (not FDA approved) from Allergan (Irvine, CA, USA) are produced from crosslinked HA in a single state (no beads) (See Table 3 for more HA dermal fillers) [3].

In the US, Hylaform ${ }^{\circledR}$ was the first HA-based filler available for use. This product was developed by Genzyme Biosurgery (New Jersey, US) and was marketed by Inamed ${ }^{\circledR}$ (Santa Barbara, CA, US) before acquisition by Allergan, Inc. (Irvine, CA, US) in 2006. Hylaform ${ }^{\circledR}$ is a sterile, colorless gel material in which HA is crosslinked with divinyl sulfone. It is FDA approved (April, 2004) and derived from an avian source (rooster comb). The HA is $20 \%$ crosslinked $(4.5-6.0 \mathrm{mg} / \mathrm{ml})$ with a particle size of $\sim 500 \mu \mathrm{m}$. The main disadvantage of this product is longevity, as most would report that the benefits generally last for 3-4 months [136]. Captique ${ }^{\mathrm{TM}}$ is the second FDA-approved (December 2009) HA filler developed by Genzyme/Inamed/Allergan; now Mentor Corporation (Santa Barbara, CA, US). Capitique ${ }^{\mathrm{TM}}$ was manufactured based on Genzyme's patented non-animal stabilized HA technology. This prevented the possibility of immunological issues related to the previous avian source HA based dermal fillers such as Hyaform ${ }^{\circledR}$. Again, the HA is $20 \%$ crosslinked by divinyl sulfone $(4.5-6.0 \mathrm{mg} / \mathrm{ml})$ and gel particle size of $\sim 500 \mu \mathrm{m}$. Captique ${ }^{\mathrm{TM}}$ was also shown to have treatment duration anywhere between 3 to 6 months [136].

The next HA-based dermal filler approved by FDA in the US was Restylane ${ }^{\circledR}$ (December, 2003). It is a non-animal HA derivative made from fermentation of equine streptococci and 
crosslinked with 1,4-butandiol diglycidylether (BDDA). The HA (20 mg/ml) is only lightly crosslinked $(1 \%)$ with a particle size of $\sim 400 \mu \mathrm{m}$. Restylane ${ }^{\circledR}$ has lower degree of crosslinking with different crosslinking chemistry, higher HA concentration, and smaller particle size comparing to previous products. The FDA approved this product for middermal applications including deep wrinkle correction, lip augmentation, nasolabial fold correction, and for glabellar creases. The application of Restylane ${ }^{\circledR}$ in clinical trials dates back to the 1990s. In two European clinical trials by Duranti et al. and Olenius (both in 1998), the duration of effect was found to be $\sim 8$ months. Restylane ${ }^{\circledR}$ has been employed for the past several years by numerous doctors with acceptable results ( $\sim 6$ to 12 months). It was reported that Restylane ${ }^{\circledR}$ can be injected easily with small-gauge needles such as gauge 30 . The major concern for Restylane ${ }^{\circledR}$ injection is mild reaction at the site of injection and pain during the injection [136]. Juvéderm ${ }^{\mathrm{TM}}$ is another dermal filler currently available in the market. It is manufactured by Lea Derm, a subdivision of Corneal Group (Paris, France). The product was developed by Inamed ${ }^{\circledR}$ (Santa Barbara, CA) and currently is distributed by Allergan Inc. (Irvine, CA, US). It is a non-animal stabilized HA containing high crosslinked HA made by Streptococcus equi bacteria. Six different formulations of Juvéderm ${ }^{\text {TM }}$ have been developed with concentrations ranging from $18 \mathrm{mg} / \mathrm{g}$ to $30 \mathrm{mg} / \mathrm{g}$. These are known to be highly viscous dermal fillers. The HA is crosslinked (6\%) with a patented single-phase BDDE chemistry, phosphate buffered to $6.5-7.3 \mathrm{pH}$ [140]. The higher HA concentration and greater crosslinking supports the notion that treatment via Juvéderm ${ }^{\mathrm{TM}}$ can last between 6 to 12 months [136].

The main differences between these dermal fillers are the source of HA, concentration, particle size of beads (if included in the formulation), degree and type of crosslinking, and inclusion or lack of anesthetic. For the available dermal fillers, the source of HA are either avian (found primarily in rooster combs) or bacteria (mostly from the synthetic fermentation of the Staphylococcus equine bacterium). The concentration of HA has an important role in dermal fillers. Dermal fillers with high HA concentration tend to have better 'volume' and longer duration of effect; however, their high viscosity can be an issue when injecting using fine needles. In all HA fillers, a single ether crosslink was typically utilized. Recently, HA fillers have utilized greater degrees of crosslinking. Crosslinking can potentially improve resistance to degradation, making for a longer lasting treatment, but increasing the difficultly of injection [3].

Current HA-based dermal fillers have maximum treatment duration up to 12 months (Table 3). To extend this treatment duration, HA with higher molecular weight or more crosslinking can be used, however injectability of the HA solution drops by increasing HA molecular weight and corsslinking. This makes the dermal filler difficult to administer, possibly producing pain for the patient. Therefore, the development of dermal filler products with enhanced injectability and longer duration is desired.

\subsection{Application of hyaluronic acid in osteoarthritis treatment}

Osteoarthritis (OA) is the most common disease associated with aging, affecting many people with about $70 \%$ of these individuals aged 65 and over. OA is characterized by the slow degradation of cartilage, pain, and increasing disability. The disease can have an impact on several aspects of a patient's life, including functional and social activities [141, 142]. Current pharmacological therapies target palliation of pain and include analgesics (i.e. acetaminophen, cyclooxygenase-2-specific inhibitors, non-steroidal anti-inflammatory drugs, tramadol, opioids), intra-articular therapies (glucocorticoids and hyaluronan), and topical treatments (i.e. capsaicin, methylsalicylate). If none of these therapies work, surgical joint replacement is the last option, which is costly and highly invasive [142]. 
Synovial spaces are the cavities of the joints that facilitate movement of adjacent bones. Synovial spaces are formed by a surface of cartilage, synovium, and synovial fluid. The synovial fluid is a clear, colorless or sometimes yellowish liquid secreted into the joint cavity by the synovioum. The synovial fluid volume is approximately $2 \mathrm{~mL}$ in normal human knee joints and contains electrolytes, low molecular weight organic molecules, and macromolecules such as glycosaminoglycans (GAGs). GAGs present in the synovial fluid are chondrotin-4-sulfate (2\%), with the remaining 98\% made up of HA [141].

The mechanical function of the synovial fluid can be attributed to its rheological properties, more specifically its viscoelastic properties. Synovial fluid viscoelasticity depends on HA concentration, molecular weight, and molecular weight distribution, and on the physical and non-covalent interactions within the HA molecule as well as with other molecules such as proteins and ions [5]. HA molecules overlap and interact though physical entanglement or temporary interactions with ions and proteins at physiological conditions. These interactions, which are dependent on HA molecular weight and concentration, determine the formation of the transient network structure that is responsible for the viscoelasticity of synovial fluid [141, 142]. In OA, HA loses these functionalities as a result of reduced HA molecular weight and concentration; thus, decreasing the viscoelastic properties of synovial fluid [95, 141, 143].

The viscoelastic behavior of synovial fluid can be described by the elastic modulus $\left(G^{\prime \prime}\right)$ and viscous modulus $\left(\mathrm{G}^{\prime \prime}\right)$ as a function of frequency $[94,95,144]$. The degradation of synovial fluid is evident from its rheological properties. Generally, aging is the main reason for a reduction in HA molecular weight or HA concentration (Table 4). After damage or aging, synovial fluid cannot provide the required viscoelastic response to compression and tangential forces arising in everyday life, allowing cartilage-cartilage contact and increasing wear of the joint surface [141, 142]. Intra-articular treatment with HA and hylans (uncrosslinked HA and crosslinked HA, respectively) has recently been accepted as a common therapy for reducing pain associated with OA [141, 142]. Currently, products such as Hyalgan ${ }^{\circledR}$ (HA), Orthovisc ${ }^{\circledR}$ (HA) and Synvisc ${ }^{\circledR}$ (hylan GF 20) are available as viscosupplements for intra-synovial injection in osteoarthritis treatment (Table 5) [141, 144146].

In the 1970s, the first studies on the application of HA for human knee OA were performed by Rydell and Balasz (1971) and Peyron and Balasz (1974). In 1974, Peyron injected different volumes of HA into 23 knees and obtained positive results; reducing pain and increasing patient function. Since then, many HA viscosupplements have been made from different sources of HA including rooster combs (Table 5). Similar to dermal fillers, increasing HA concentration and the degree of crosslinking can enhance the performance viscosupplements for OA treatment; however, the high viscosity of these modified products may cause difficulties during administration [97]. In 1997, the FDA approved HA viscosupplementation for OA treatment. Currently, several viscosupplements including Hyalgan $\AA$, Supartz $\AA$, Orthovisc $\AA$, Synvisc ${ }^{\circledR}$, and Euflexxa ${ }^{\circledR}$ are available on the market. Each of these products differ in their method of production, molecular weight, dosing instructions, and possibly clinical outcomes [147].

Several clinical trials have demonstrated the efficacy and tolerability of intraarticular HA for the treatment of pain associated with OA. These studies have shown three injections of Synvisc ${ }^{\circledR}$ (crosslinked HA) can provide relief of knee pain up to 6 months. A competing product, Hyalgan ${ }^{\circledR}$ (sodium hyaluronate solution), requires 6 injections to reach the same efficacy of Synvisc ${ }^{\circledR}[97,145,148,149]$. While Synvisc ${ }^{\circledR}$ was shown to be more efficient in reducing pain, its structure (high molecular weight HA due to crosslinking) increases the force required to inject (Table 6). Unlike Synvisc ${ }^{\circledR}$, Hyalgan ${ }^{\circledR}$ has a lower viscosity, 
making injection easier, but Hyalgan ${ }^{\circledR}$ is not as effective as Synvisc ${ }^{\circledR}$ due to lower viscoelastic properties (elastic and viscous moduli) [144, 145, 149]. Moreover, Orthovisc®, one of the viscosupplements with the highest HA concentration, has lower viscosity than Synvisc ${ }^{\circledR}$ but it is not reported to be as effective as Synvisc ${ }^{\circledR}[144,145,149]$. This creates a need for development of products with enhanced injectability and yet reasonable viscoelastic behavior (Synvisc ${ }^{\circledR}$ elastic and viscous moduli values) for osteoarthritis treatment.

\section{Conclusion}

Hyaluronic acid is a naturally occurring biomolecule abundantly available in body tissues and fluids. Due to the prevalence of hyaluronic acid in the body and its desirable properties, HA has been utilized in several types of biomedical products. This article reviewed the physical and chemical characteristics of HA as applied to tissue engineering, dermal filling, and viscosupplementation. In each application, difficulties such as potential toxicity of crosslinking techniques, high viscosity of HA solutions, and rapid elimination have been raised as limitations to improve biomedical products derived from HA. To overcome these limitations, current and emerging strategies to modify HA were reviewed as potential approaches.

Other biomedical applications of HA are also emerging (e.g. drug conjugation and delivery, therapeutic and/or immune modulation effects, etc.). New chemical modifications performed on HA are also appearing in the literature. In particular, new strategies for safely crosslinking HA in situ represent an important paradigm for generating new strategies for tissue engineering and viscosupplementation. Formulations that improve product performance will also utilize physical interactions between components (e.g. interactions between HA nanoparticles). Utilizing particle/polymer or particle/particle interactions may provide new approaches to tune the viscoelastic properties of HA formulations as applied to tissue engineering, dermal filling, and osteoarthritis treatment.

\section{References}

[1]. Kurisawa M, Chung J, Yang Y, Gao S, Uyama H. Injectable biodegradable hydrogels composed of hyaluronic acid-tyramine conjugates for drug delivery and tissue engineering. Chemical communications. 2005; 2005:4312-4. [PubMed: 16113732]

[2]. Garg, HG.; Hales, CA. Chemistry and biology of hyaluronan. Elsevier Science; 2004. ISBN: 978-0-08-044382-9

[3]. Andre P. New trends in face rejuvenation by hyaluronic acid injections. Journal of Cosmetic Dermatology. 2008; 7:251-8. [PubMed: 19146600]

[4]. Necas J, Bartosikova L, Brauner P, Kolar J. Hyaluronic acid (hyaluronan): a review. Veterinarni Medicina. 2008; 53:397-411.

[5]. Falcone, S.; Palmeri, D.; Berg, R. Biomedical applications of hyaluronic acid. ACS Publications; 2006. p. 155-74.

[6]. Zheng Shu X, Liu Y, Palumbo F, Luo Y, Prestwich G. In situ crosslinkable hyaluronan hydrogels for tissue engineering. Biomaterials. 2004; 25:1339-48. [PubMed: 14643608]

[7]. Vejlens L. Glycosaminoglycans of human bone tissue. Calcified Tissue International. 1971; 7:175-90.

[8]. Dumitriu, S. Polymeric biomaterials. Marcel Dekker Inc.; New York: 2002. ISBN 0-8247-8969-5

[9]. Segura T, Anderson B, Chung P, Webber R, Shull K, Shea L. Crosslinked hyaluronic acid hydrogels: a strategy to functionalize and pattern. Biomaterials. 2005; 26:359-71. [PubMed: 15275810]

[10]. Toole B. Hyaluronan: from extracellular glue to pericellular cue. Nature Reviews Cancer. 2004; 4:528-39. 
[11]. Cai S, Xie Y, Bagby T, Cohen M, Forrest M. Intralymphatic chemotherapy using a hyaluronancisplatin conjugate. The Journal of surgical research. 2008; 147:247. [PubMed: 18498877]

[12]. UNDERHILL C. CD44: the hyaluronan receptor. Journal of Cell Science. 1992; 103:293. [PubMed: 1282514]

[13]. Eng D, Caplan M, Preul M, Panitch A. Hyaluronan Scaffolds-A Balance between Backbone Functionalization and Bioactivity. Acta Biomaterialia. 2010; 6:2407-14. [PubMed: 20051273]

[14]. Kim J, Kim I, Cho T, Lee K, Hwang S, Tae G, et al. Bone regeneration using hyaluronic acidbased hydrogel with bone morphogenic protein-2 and human mesenchymal stem cells. Biomaterials. 2007; 28:1830-7. [PubMed: 17208295]

[15]. Luo Y, Kirker K, Prestwich G. Cross-linked hyaluronic acid hydrogel films: new biomaterials for drug delivery. Journal of controlled release. 2000; 69:169-84. [PubMed: 11018555]

[16]. Lee K, Mooney D. Hydrogels for tissue engineering. Chem Rev. 2001; 101:1869-80. [PubMed: 11710233]

[17]. Drury J, Mooney D. Hydrogels for tissue engineering: scaffold design variables and applications. Biomaterials. 2003; 24:4337-51. [PubMed: 12922147]

[18]. Burdick JA, Prestwich GD. Hyaluronic Acid Hydrogels for Biomedical Applications. Advanced Materials. 23:H41-H56.

[19]. Campo GM, Avenoso A, Campo S, Ferlazzo AM, Micali C, Zanghì L, et al. Hyaluronic acid and chondroitin-4-sulphate treatment reduces damage in carbon tetrachloride-induced acute rat liver injury. Life sciences. 2004; 74:1289-305. [PubMed: 14697411]

[20]. Yadav AK, Mishra P, Agrawal GP. An insight on hyaluronic acid in drug targeting and drug delivery. Journal of drug targeting. 2008; 16:91-107. [PubMed: 18274931]

[21]. Rossi S, Sandri G, Caramella CM. Buccal drug delivery: A challenge already won? Drug Discovery Today: Technologies. 2005; 2:59-65.

[22]. Hamidi M, Azadi A, Rafiei P. Hydrogel nanoparticles in drug delivery. Advanced drug delivery reviews. 2008; 60:1638-49. [PubMed: 18840488]

[23]. Whelan, J. The Biology of hyaluronan. John Wiley \& Sons; 1989. ISBN: 0471923052

[24]. Sheehan J, Arundel C, Phelps C. Effect of the cations sodium, potassium and calcium on the interaction of hyaluronate chains: a light scattering and viscometric study. International Journal of Biological Macromolecules. 1983; 5:222-8.

[25]. Toole, BP. Hyaluronan in morphogenesis. Elsevier; 2001. p. 79-87.

[26]. Toole BP, Wight TN, Tammi MI. Hyaluronan-cell interactions in cancer and vascular disease. Journal of Biological Chemistry. 2002; 277:4593. [PubMed: 11717318]

[27]. Noble PW. Hyaluronan and its catabolic products in tissue injury and repair. Matrix biology. 2002; 21:25-9. [PubMed: 11827789]

[28]. Toole B. Hyaluronan in morphogenesis. Journal of internal medicine. 1997; 242:35-40. [PubMed: 9260564]

[29]. Turley EA, Noble PW, Bourguignon LY. Signaling properties of hyaluronan receptors. Journal of Biological Chemistry. 2002; 277:4589-92. [PubMed: 11717317]

[30]. Christofori G. Changing neighbours, changing behaviour: cell adhesion molecule-mediated signalling during tumour progression. The EMBO journal. 2003; 22:2318-23. [PubMed: 12743026]

[31]. Lee TH, Wisniewski H-G, Vilcek J. A novel secretory tumor necrosis factor-inducible protein (TSG-6) is a member of the family of hyaluronate binding proteins, closely related to the adhesion receptor CD44. The Journal of cell biology. 1992; 116:545-57. [PubMed: 1730767]

[32]. Perides G, Asher R, Lark M, Lane W, Robinson R, Bignami A. Glial hyaluronate-binding protein: a product of metalloproteinase digestion of versican? Biochemical Journal. 1995; 312:377. [PubMed: 8526845]

[33]. Perides G, Asher R, Dahl D, Bignamic A. Glial hyaluronate-binding protein (GHAP) optic nerve and retina. Brain research. 1990; 512:309-16. [PubMed: 1693869]

[34]. Leppilahti M, Hellström P, Tammela TL. Effect of diagnostic hydrodistension and four intravesical hyaluronic acid instillations on bladder ICAM-1 intensity and association of ICAM-1 
intensity with clinical response in patients with interstitial cystitis. Urology. 2002; 60:46-51. [PubMed: 12100920]

[35]. Weigel JA, Raymond RC, Weigel PH. The hyaluronan receptor for endocytosis (HARE) is not CD44 or CD54 (ICAM-1). Biochemical and biophysical research communications. 2002; 294:918-22. [PubMed: 12061795]

[36]. Banerji S, Ni J, Wang S-X, Clasper S, Su J, Tammi R, et al. LYVE-1, a new homologue of the CD44 glycoprotein, is a lymph-specific receptor for hyaluronan. The Journal of cell biology. 1999; 144:789-801. [PubMed: 10037799]

[37]. Carreira CM, Nasser SM, di Tomaso E, Padera TP, Boucher Y, Tomarev SI, et al. LYVE-1 is not restricted to the lymph vessels expression in normal liver blood sinusoids and down-regulation in human liver cancer and cirrhosis. Cancer research. 2001; 61:8079-84. [PubMed: 11719431]

[38]. Jackson DG. The lymphatics revisited: new perspectives from the hyaluronan receptor LYVE- 1. Trends in cardiovascular medicine. 2003; 13:1-7. [PubMed: 12554094]

[39]. Prevo R, Banerji S, Ferguson DJ, Clasper S, Jackson DG. Mouse LYVE-1 is an endocytic receptor for hyaluronan in lymphatic endothelium. Journal of Biological Chemistry. 2001; 276:19420-30. [PubMed: 11278811]

[40]. Akira S, Tokeda K, Kaisho T. Toll-like receptors: critical proteins linking innate and acquired immunity. Nature immunology. 2001; 2:675-80. [PubMed: 11477402]

[41]. Takeda K, Akira S. Toll-like receptors. Current Protocols in Immunology. 2007; 14:2. 1-2. 3.

[42]. Rock FL, Hardiman G, Timans JC, Kastelein RA, Bazan JF. A family of human receptors structurally related to Drosophila Toll. Proceedings of the National Academy of Sciences. 1998; 95:588-93.

[43]. Rescigno M, Granucci F, Ricciardi-Castagnoli P. Molecular Events of Bacterial-Induced Maturation ofDendritic Cells. Journal of clinical immunology. 2000; 20:161-6. [PubMed: 10941823]

[44]. Poltorak A, He X, Smirnova I, Liu M-Y, Van Huffel C, Du X, et al. Defective LPS signaling in $\mathrm{C} 3 \mathrm{H} / \mathrm{HeJ}$ and C57BL/10ScCr mice: mutations in Tlr4 gene. Science. 1998; 282:2085-8. [PubMed: 9851930]

[45]. Takeuchi O, Hoshino K, Kawai T, Sanjo H, Takada H, Ogawa T, et al. Differential roles of TLR2 and TLR4 in recognition of gram-negative and gram-positive bacterial cell wall components. Immunity. 1999; 11:443-51. [PubMed: 10549626]

[46]. McKee CM, Penno MB, Cowman M, Burdick MD, Strieter RM, Bao C, et al. Hyaluronan (HA) fragments induce chemokine gene expression in alveolar macrophages. The role of HA size and CD44. Journal of Clinical Investigation. 1996; 98:2403. [PubMed: 8941660]

[47]. Gariboldi S, Palazzo M, Zanobbio L, Selleri S, Sommariva M, Sfondrini L, et al. Low molecular weight hyaluronic acid increases the self-defense of skin epithelium by induction of $\beta$-defensin 2 via TLR2 and TLR4. The Journal of Immunology. 2008; 181:2103-10. [PubMed: 18641349]

[48]. Scheibner KA, Lutz MA, Boodoo S, Fenton MJ, Powell JD, Horton MR. Hyaluronan fragments act as an endogenous danger signal by engaging TLR2. The Journal of Immunology. 2006; 177:1272-81. [PubMed: 16818787]

[49]. Oertli B, Fan X, Wüthrich RP. Characterization of CD44-mediated hyaluronan binding by renal tubular epithelial cells. Nephrology Dialysis Transplantation. 1998; 13:271.

[50]. Chen WYJ, Abatangelo G. Functions of hyaluronan in wound repair. Wound Repair and Regeneration. 1999; 7:79-89. [PubMed: 10231509]

[51]. Wisniewski H-G, Hua J, Poppers DM, Naime D, Vilcek J, Cronstein BN. TNF/IL-1-inducible protein TSG-6 potentiates plasmin inhibition by inter-alpha-inhibitor and exerts a strong antiinflammatory effect in vivo. The Journal of Immunology. 1996; 156:1609-15. [PubMed: 8568267]

[52]. Kobayashi H, Terao T. Hyaluronic acid-specific regulation of cytokines by human uterine fibroblasts. American Journal of Physiology-Cell Physiology. 1997; 273:C1151-C9.

[53]. Laurent, TC. The chemistry, biology and medical applications of hyaluronan and its derivatives. Portland Pr: 1998. 
[54]. Barnhart B, Cox S, Kraemer P. Detachment variants of Chinese hamster cells: hyaluronic acid as a modulator of cell detachment. Experimental Cell Research. 1979; 119:327-32. [PubMed: 218830]

[55]. Mohamadzadeh M, DeGrendele H, Arizpe H, Estess P, Siegelman M. Proinflammatory stimuli regulate endothelial hyaluronan expression and CD44/HA-dependent primary adhesion. Journal of Clinical Investigation. 1998; 101:97. [PubMed: 9421471]

[56]. Liu Y, Zheng Shu X, Prestwich GD. Biocompatibility and stability of disulfide-crosslinked hyaluronan films. Biomaterials. 2005; 26:4737-46. [PubMed: 15763253]

[57]. Brecht M, Mayer U, Schlosser E, Prehm P. Increased hyaluronate synthesis is required for fibroblast detachment and mitosis. Biochemical Journal. 1986; 239:445. [PubMed: 3101667]

[58]. Mian N. Analysis of cell-growth-phase-related variations in hyaluronate synthase activity of isolated plasma-membrane fractions of cultured human skin fibroblasts. Biochemical Journal. 1986; 237:333. [PubMed: 3099751]

[59]. Abatangelo G, Cortivo R, Martelli M, Vecchia P. Cell detachment mediated by hyaluronic acid. Experimental cell research. 1982; 137:73-8. [PubMed: 7056288]

[60]. Morriss-Kay GM, Tuckett F, Solursh M. The effects of Streptomyces hyaluronidase on tissue organization and cell cycle time in rat embryos. Journal of embryology and experimental morphology. 1986; 98:59-70. [PubMed: 3655652]

[61]. Turley E, Austen L, Moore D, Hoare K. Ras-transformed cells express both CD44 and RHAMM hyaluronan receptors: only RHAMM is essential for hyaluronan-promoted locomotion. Experimental cell research. 1993; 207:277. [PubMed: 7688314]

[62]. Chen W, Grant ME, Schor A, Schor S. Differences between adult and foetal fibroblasts in the regulation of hyaluronate synthesis: correlation with migratory activity. Journal of cell science. 1989; 94:577-84. [PubMed: 2632585]

[63]. Ellis I, Grey A, Schor AM, Schor SL. Antagonistic effects of TGF-beta 1 and MSF on fibroblast migration and hyaluronic acid synthesis. Possible implications for dermal wound healing. Journal of cell science. 1992; 102:447-56. [PubMed: 1506427]

[64]. Ellis I, Banyard J, Schor S. Differential response of fetal and adult fibroblasts to cytokines: cell migration and hyaluronan synthesis. Development. 1997; 124:1593-600. [PubMed: 9108375]

[65]. Wang C, Thor AD, Moore D, Zhao Y, Kerschmann R, Stern R, et al. The overexpression of RHAMM, a hyaluronan-binding protein that regulates ras signaling, correlates with overexpression of mitogen-activated protein kinase and is a significant parameter in breast cancer progression. Clinical cancer research. 1998; 4:567-76. [PubMed: 9533523]

[66]. Hall C, Lange L, Prober D, Zhang S, Turley E. pp60 (c-src) is required for cell locomotion regulated by the hyaluronanreceptor RHAMM. Oncogene. 1996; 13:2213. [PubMed: 8950989]

[67]. Pratt R, Larsen M, Johnston M. Migration of cranial neural crest cells in a cell-free hyaluronaterich matrix. Developmental biology. 1975; 44:298-305. [PubMed: 1132595]

[68]. Turley EA. Hyaluronan-binding proteins and receptors. Advanced drug delivery reviews. 1991; 7:257-64.

[69]. Thomas L, Byers HR, Vink J, Stamenkovic I. CD44H regulates tumor cell migration on hyaluronate-coated substrate. The Journal of cell biology. 1992; 118:971-7. [PubMed: 1380003]

[70]. Rooney P, Wang M, Kumar P, Kumar S. Angiogenic oligosaccharides of hyaluronan enhance the production of collagens by endothelial cells. Journal of Cell Science. 1993; 105:213-8. [PubMed: 7689574]

[71]. Noble PW, Lake F, Henson P, Riches D. Hyaluronate activation of CD44 induces insulin-like growth factor-1 expression by a tumor necrosis factor-alpha-dependent mechanism in murine macrophages. Journal of Clinical Investigation. 1993; 91:2368. [PubMed: 8514850]

[72]. Noble PW, McKee CM, Cowman M, Shin HS. Hyaluronan fragments activate an NF-kappa B/Ikappa B alpha autoregulatory loop in murine macrophages. The Journal of experimental medicine. 1996; 183:2373-8. [PubMed: 8642348]

[73]. Dvorak H, Harvey V, Estrella P, Brown L, McDonagh J, Dvorak A. Fibrin containing gels induce angiogenesis. Implications for tumor stroma generation and wound healing. Laboratory investigation; a journal of technical methods and pathology. 1987; 57:673. 
[74]. West DC, Kumar S. The effect of hyaluronate and its oligosaccharides on endothelial cell proliferation and monolayer integrity. Experimental cell research. 1989; 183:179-96. [PubMed: 2472284]

[75]. Lees VC, Fan T, West DC. Angiogenesis in a delayed revascularization model is accelerated by angiogenic oligosaccharides of hyaluronan. Laboratory investigation; a journal of technical methods and pathology. 1995; 73:259.

[76]. Arnold F, Jia C, He C, Cherry GW, Carbow B, Meyer-Ingold W, et al. Hyaluronan, heterogeneity, and healing: The effects of ultrapure hyaluronan of defined molecular size on the repair of full-thickness pig skin wounds. Wound Repair and Regeneration. 2002; 3:299-310. [PubMed: 17173556]

[77]. Sattar A, Rooney P, Kumar S, Pye D, West DC, Scott I, et al. Application of angiogenic oligosaccharides of hyaluronan increases blood vessel numbers in rat skin. Journal of investigative dermatology. 1994; 103:576-9. [PubMed: 7523533]

[78]. West D, Shaw D. Tumour hyaluronan in relation to angiogenesis and metastasis. WENNER GREN INTERNATIONAL SERIES. 1998:227-34.

[79]. Mast BA, Haynes JH, Krummel TM, Diegelmann RF, Cohen IK. In vivo degradation of fetal wound hyaluronic acid results in increased fibroplasia, collagen deposition, and neovascularization. Plastic and reconstructive surgery. 1992; 89:503. [PubMed: 1371361]

[80]. Tammi R, Ripellino JA, Margolis RU, Tammi M. Localization of epidermal hyaluronic acid using the hyaluronate binding region of cartilage proteoglycan as a specific probe. Journal of Investigative Dermatology. 1988; 90:412-4. [PubMed: 2450149]

[81]. Tammi R, Ripellino JA, Margolis RU, Maibach HI, Tammi M. Hyaluronate accumulation in human epidermis treated with retinoic acid in skin organ culture. Journal of investigative dermatology. 1989; 92:326-32. [PubMed: 2465358]

[82]. Wang C, Tammi M, Tammi R. Distribution of hyaluronan and its CD44 receptor in the epithelia of human skin appendages. Histochemistry and Cell Biology. 1992; 98:105-12.

[83]. Tuhkanen A-L, Tammi M, Pelttari A, Ågren UM, Tammi R. Ultrastructural analysis of human epidermal CD44 reveals preferential distribution on plasma membrane domains facing the hyaluronan-rich matrix pouches. Journal of Histochemistry \& Cytochemistry. 1998; 46:241-8. [PubMed: 9446831]

[84]. Kaya G, Rodriguez I, Jorcano JL, Vassalli P, Stamenkovic I. Selective suppression ofCD44 in keratinocytes of mice bearing an antisense CD44 transgene driven by a tissue-specific promoter disrupts hyaluronate metabolism in the skin and impairs keratinocyte proliferation. Genes \& development. 1997; 11:996-1007. [PubMed: 9136928]

[85]. Longaker MT, Chiu ES, Adzick NS, Stern M, Harrison MR, Stern R. Studies in fetal wound healing. V. A prolonged presence of hyaluronic acid characterizes fetal wound fluid. Annals of surgery. 1991; 213:292. [PubMed: 2009010]

[86]. West DC, Shaw DM, Lorenz P, Adzick NS, Longaker MT. Fibrotic healing of adult and late gestation fetal wounds correlates with increased hyaluronidase activity and removal of hyaluronan. The international journal of biochemistry \& cell biology. 1997; 29:201-10.

[87]. Lee JY, Spicer AP. Hyaluronan: a multifunctional, megaDalton, stealth molecule. Current Opinion in Cell Biology. 2000; 12:581-6. [PubMed: 10978893]

[88]. Ramamurthi A, Vesely I. Evaluation of the matrix-synthesis potential of crosslinked hyaluronan gels for tissue engineering of aortic heart valves. Biomaterials. 2005; 26:999-1010. [PubMed: 15369688]

[89]. Cowman MK, Matsuoka S. Experimental approaches to hyaluronan structure. Carbohydrate research. 2005; 340:791-809. [PubMed: 15780246]

[90]. Laurent TC, Fraser J. Hyaluronan. The FASEB Journal. 1992; 6:2397-404.

[91]. Stern R, Kogan G, Jedrzejas MJ, Soltés L. The many ways to cleave hyaluronan. Biotechnology advances. 2007; 25:537-57. [PubMed: 17716848]

[92]. Volpi N, Schiller J, Stern R, Soltes L. Role, metabolism, chemical modifications and applications of hyaluronan. Current medicinal chemistry. 2009; 16:1718-45. [PubMed: 19442142] 
[93]. Šoltés L, Mendichi R, Kogan G, Schiller J, Stankovska M, Arnhold J. Degradative action of reactive oxygen species on hyaluronan. Biomacromolecules. 2006; 7:659-68. [PubMed: 16529395]

[94]. Maheu E, Ayral X, Dougados M. A hyaluronan preparation (500-730 kDa) in the treatment of osteoarthritis: a review of clinical trials with Hyalgan. International journal of clinical practice. 2002; 56:804. [PubMed: 12510956]

[95]. Arrich J, Piribauer F, Mad P, Schmid D, Klaushofer K, Müllner M. Intra-articular hyaluronic acid for the treatment of osteoarthritis of the knee: systematic review and meta-analysis. Canadian Medical Association Journal. 2005; 172:1039. [PubMed: 15824412]

[96]. Goldberg V, Buckwalter J. Hyaluronans in the treatment of osteoarthritis of the knee: evidence for disease-modifying activity. Osteoarthritis and cartilage. 2005; 13:216-24. [PubMed: 15727888]

[97]. Migliore A, Granata M. Intra-articular use of hyaluronic acid in the treatment of osteoarthritis. Clinical interventions in aging. 2008; 3:365. [PubMed: 18686758]

[98]. Allison DD, Grande-Allen KJ. Review. Hyaluronan: a powerful tissue engineering tool. Tissue Engineering. 2006; 12:2131-40. [PubMed: 16968154]

[99]. Jiang D, Liang J, Noble PW. Hyaluronan in tissue injury and repair. Annu Rev Cell Dev Biol. 2007; 23:435-61. [PubMed: 17506690]

[100]. Tomihata K, Ikada Y. Crosslinking of hyaluronic acid with water soluble carbodiimide. Journal of biomedical materials research. 1997; 37:243-51. [PubMed: 9358318]

[101]. Vercruysse KP, Marecak DM, Marecek JF, Prestwich GD. Synthesis and in vitro degradation of new polyvalent hydrazide cross-linked hydrogels of hyaluronic acid. Bioconjugate chemistry. 1997; 8:686-94. [PubMed: 9327132]

[102]. Luo Y, Kirker KR, Prestwich GD. Cross-linked hyaluronic acid hydrogel films: new biomaterials for drug delivery. Journal of controlled release. 2000; 69:169-84. [PubMed: 11018555]

[103]. Baier Leach J, Bivens KA, Patrick CW Jr, Schmidt CE. Photocrosslinked hyaluronic acid hydrogels: natural, biodegradable tissue engineering scaffolds. Biotechnology and bioengineering. 2003; 82:578-89. [PubMed: 12652481]

[104]. Leach JB, Bivens KA, Collins CN, Schmidt CE. Development of photocrosslinkable hyaluronic acid-polyethylene glycol-peptide composite hydrogels for soft tissue engineering. Journal of Biomedical Materials Research Part A. 2004; 70:74-82. [PubMed: 15174111]

[105]. Balazs EA, Denlinger JL. Viscosupplementation: A new concept in the treatment of osteoarthritis. The Journal of rheumatology Supplement. 1993; 39:3. [PubMed: 8410881]

[106]. Jin Y, Yamanaka J, Sato S, Miyata I, Yomota C, Yonese M. Recyclable characteristics of hyaluronate-polyhydroxyethyl acrylate blend hydrogel for controlled releases. Journal of controlled release. 2001; 73:173-81. [PubMed: 11516495]

[107]. Weng L, Gouldstone A, Wu Y, Chen W. Mechanically strong double network photocrosslinked hydrogels from N,N-dimethylacrylamide and glycidyl methacrylated hyaluronan. Biomaterials. 2008; 29:2153-63. [PubMed: 18272215]

[108]. Jia X, Burdick JA, Kobler J, Clifton RJ, Rosowski JJ, Zeitels SM, et al. Synthesis and characterization of in situ cross-linkable hyaluronic acid-based hydrogels with potential application for vocal fold regeneration. Macromolecules. 2004; 37:3239-48.

[109]. Miyamoto K, Sasaki M, Minamisawa Y, Kurahashi Y, Kano H, Ishikawa S. Evaluation of in vivo biocompatibility and biodegradation of photocrosslinked hyaluronate hydrogels (HADgels). Journal of Biomedical Materials Research Part A. 2004; 70:550-9. [PubMed: 15307159]

[110]. Burdick JA, Chung C, Jia X, Randolph MA, Langer R. Controlled degradation and mechanical behavior of photopolymerized hyaluronic acid networks. Biomacromolecules. 2005; 6:386-91. [PubMed: 15638543]

[111]. Brigham MD, Bick A, Lo E, Bendali A, Burdick JA, Khademhosseini A. Mechanically robust and bioadhesive collagen and photocrosslinkable hyaluronic acid semi-interpenetrating networks. Tissue Engineering Part A. 2008; 15:1645-53. [PubMed: 19105604]

[112]. Ifkovits JL, Tous E, Minakawa M, Morita M, Robb JD, Koomalsingh KJ, et al. Injectable hydrogel properties influence infarct expansion and extent of postinfarction left ventricular 
remodeling in an ovine model. Proceedings of the National Academy of Sciences. 2010; 107:11507-12.

[113]. Masters KS, Shah DN, Walker G, Leinwand LA, Anseth KS. Designing scaffolds for valvular interstitial cells: cell adhesion and function on naturally derived materials. Journal of Biomedical Materials Research Part A. 2004; 71:172-80. [PubMed: 15368267]

[114]. Figallo E, Cannizzaro C, Gerecht S, Burdick JA, Langer R, Elvassore N, et al. Micro-bioreactor array for controlling cellular microenvironments. Lab Chip. 2007; 7:710-9. [PubMed: 17538712]

[115]. Cen L, Neoh K, Li Y, Kang E. Assessment of in vitro bioactivity of hyaluronic acid and sulfated hyaluronic acid functionalized electroactive polymer. Biomacromolecules. 2004; 5:2238-46. [PubMed: 15530038]

[116]. Collier JH, Camp JP, Hudson TW, Schmidt CE. Synthesis and characterization of polypyrrolehyaluronic acid composite biomaterials for tissue engineering applications. Journal of biomedical materials research. 2000; 50:574-84. [PubMed: 10756316]

[117]. Lee JY, Schmidt CE. Pyrrole-hyaluronic acid conjugates for decreasing cell binding to metals and conducting polymers. Acta biomaterialia. 2010; 6:4396-404. [PubMed: 20558330]

[118]. Aigner J, Tegeler J, Hutzler P, Campoccia D, Pavesio A, Hammer C, et al. Cartilage tissue engineering with novel nonwoven structured biomaterial based on hyaluronic acid benzyl ester. Journal of biomedical materials research. 1998; 42:172-81. [PubMed: 9773813]

[119]. Ibrahim S, Kang QK, Ramamurthi A. The impact of hyaluronic acid oligomer content on physical, mechanical, and biologic properties of divinyl sulfone crosslinked hyaluronic acid hydrogels. Journal of Biomedical Materials Research Part A. 2010; 94:355-70. [PubMed: 20186732]

[120]. Shu XZ, Liu Y, Palumbo F, Prestwich GD. Disulfide-crosslinked hyaluronan-gelatin hydrogel films: a covalent mimic of the extracellular matrix for in vitro cell growth. Biomaterials. 2003; 24:3825-34. [PubMed: 12818555]

[121]. Shu XZ, Liu Y, Luo Y, Roberts MC, Prestwich GD. Disulfide cross-linked hyaluronan hydrogels. Biomacromolecules. 2002; 3:1304-11. [PubMed: 12425669]

[122]. Serban MA, Scott A, Prestwich GD. Use of hyaluronan-derived hydrogels for three-dimensional cell culture and tumor xenografts. Curr Protoc Cell Biol. 2008; 10:1.

[123]. Prestwich GD. Hyaluronic acid-based clinical biomaterials derived for cell and molecule delivery in regenerative medicine. Journal of controlled release. 2011; 155:193-9. [PubMed: 21513749]

[124]. Jha AK, Hule RA, Jiao T, Teller SS, Clifton RJ, Duncan RL, et al. Structural analysis and mechanical characterization of hyaluronic acid-based doubly cross-linked networks. Macromolecules. 2009; 42:537-46. [PubMed: 20046226]

[125]. Darr A, Calabro A. Synthesis and characterization of tyramine-based hyaluronan hydrogels. Journal of Materials Science: Materials in Medicine. 2009; 20:33-44. [PubMed: 18668211]

[126]. Crescenzi V, Cornelio L, Di Meo C, Nardecchia S, Lamanna R. Novel hydrogels via click chemistry: synthesis and potential biomedical applications. Biomacromolecules. 2007; 8:184450. [PubMed: 17523655]

[127]. Zheng Shu X, Liu Y, Palumbo FS, Luo Y, Prestwich GD. In situ crosslinkable hyaluronan hydrogels for tissue engineering. Biomaterials. 2004; 25:1339-48. [PubMed: 14643608]

[128]. Yeo Y, Highley CB, Bellas E, Ito T, Marini R, Langer R, et al. In situ cross-linkable hyaluronic acid hydrogels prevent post-operative abdominal adhesions in a rabbit model. Biomaterials. 2006; 27:4698-705. [PubMed: 16750564]

[129]. Yeo Y, Ito T, Bellas E, Highley CB, Marini R, Kohane DS. In situ cross-linkable hyaluronan hydrogels containing polymeric nanoparticles for preventing postsurgical adhesions. Annals of surgery. 2007; 245:819. [PubMed: 17457177]

[130]. Tezel A, Fredrickson GH. The science of hyaluronic acid dermal fillers. Journal of Cosmetic and Laser Therapy. 2008; 10:35-42. [PubMed: 18330796]

[131]. Sadick NS, Karcher C, Palmisano L. Cosmetic dermatology of the aging face. Clinics in Dermatology. 2009; 27:S3-S12.

[132]. Fisher GJ, Varani J, Voorhees JJ. Looking older: fibroblast collapse and therapeutic implications. Archives of dermatology. 2008; 144:666. [PubMed: 18490597] 
[133]. Sánchez-Carpintero I, Candelas D, Ruiz-Rodríguez R. Dermal Fillers: Types, Indications, and Complications. Actas Dermo-Sifiliográficas (English Edition). 2010; 101:381-93.

[134]. CHRISTENSEN LH. Host tissue interaction, fate, and risks of degradable and nondegradable gel fillers. Dermatologic Surgery. 2009; 35:1612-9. [PubMed: 19807755]

[135]. Brandt FS, Cazzaniga A. Hyaluronic acid gel fillers in the management of facial aging. Clinical interventions in aging. 2008; 3:153. [PubMed: 18488885]

[136]. Gold MH. Use of hyaluronic acid fillers for the treatment of the aging face. Clinical interventions in aging. 2007; 2:369. [PubMed: 18044187]

[137]. Buck I, Donald W, Alam M, Kim J. Injectable fillers for facial rejuvenation: a review. Journal of Plastic, Reconstructive \& Aesthetic Surgery. 2009; 62:11-8.

[138]. Monheit GD, Prather CL. Hyaluronic acid fillers for the male patient. Dermatologic therapy. 2007; 20:394-406. [PubMed: 18093013]

[139]. Kablik J, Monhit GD, Yu L, Chang G, Gershkovich J. Comparative physical properties of hyaluronic acid dermal fillers. Dermatologic Surgery. 2009; 35:302-12. [PubMed: 19207319]

[140]. Stroumpoulis D, Mudd CS, Tezel A. Polysaccaride gel formation having increased longevity. Google Patents. 2008

[141]. Moreland LW. Intra-articular hyaluronan (hyaluronic acid) and hylans for the treatment of osteoarthritis: mechanisms of action. Arthritis Research and Therapy. 2003; 5:54-67. [PubMed: 12718745]

[142]. Yaszemski, MJ. Tissue engineering and novel delivery systems. CRC Press; 2003. ISBN: 08247-4786-0

[143]. Conrad, BP. The effects of glucosamine and chondroitin on the viscosity of synovial fluid in patients with osteoarthritis. Citeseer; 2001.

[144]. Altman R, Moskowitz R. Intraarticular sodium hyaluronate (Hyalgan) in the treatment of patients with osteoarthritis of the knee: a randomized clinical trial. Hyalgan Study Group. The Journal of rheumatology. 1998; 25:2203. [PubMed: 9818665]

[145]. Watterson JR, Esdaile JM. Viscosupplementation: therapeutic mechanisms and clinical potential in osteoarthritis of the knee. Journal of the American Academy of Orthopaedic Surgeons. 2000; 8:277. [PubMed: 11029555]

[146]. CARE FONP. Hyaluronic acid products for osteoarthritis of the knee. CPJ. 2007; 140:195.

[147]. Sun SF, Chou YJ, Hsu CW, Chen WL. Hyaluronic acid as a treatment for ankle osteoarthritis. Current reviews in musculoskeletal medicine. 2009; 2:78-82. [PubMed: 19468874]

[148]. Leopold SS, Warme WJ, Pettis PD, Shott S. Increased frequency of acute local reaction to intraarticular hylan GF-20 (synvisc) in patients receiving more than one course of treatment. The Journal of bone and joint surgery American volume. 2002; 84:1619. [PubMed: 12208919]

[149]. Kotevoglu N, Iy bozkurt PC, H z O, Toktas H, Kuran B. A prospective randomised controlled clinical trial comparing the efficacy of different molecular weight hyaluronan solutions in the treatment of knee osteoarthritis. Rheumatology international. 2006; 26:325-30. [PubMed: 15959784]

[150]. Fam H, Bryant J, Kontopoulou M. Rheological properties of synovial fluids. Biorheology. 2007; 44:59-74. [PubMed: 17538199] 


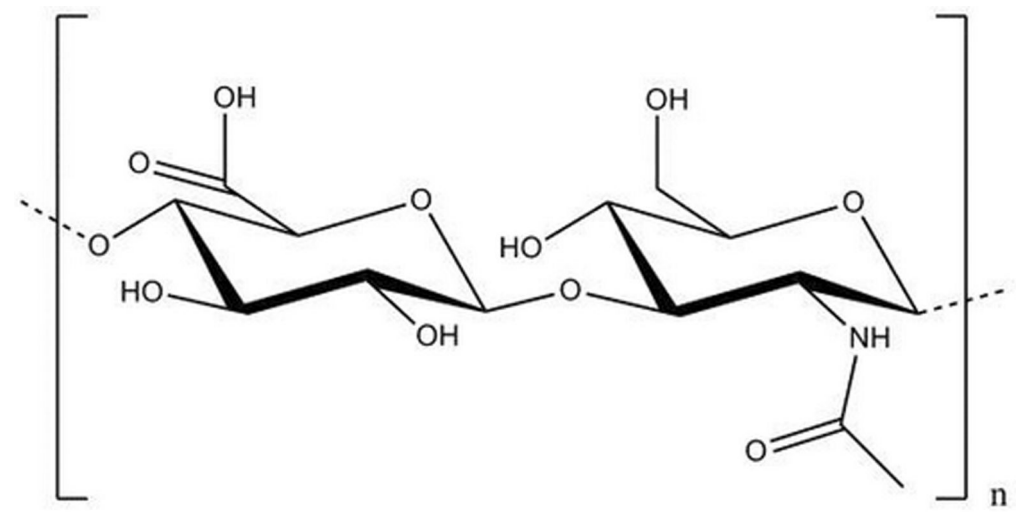

Figure (1).

Chemical structure of hyaluronic acid (HA), which is made of disaccharide repeats of $N$ acetylglucosamine and glucuronic acid. 


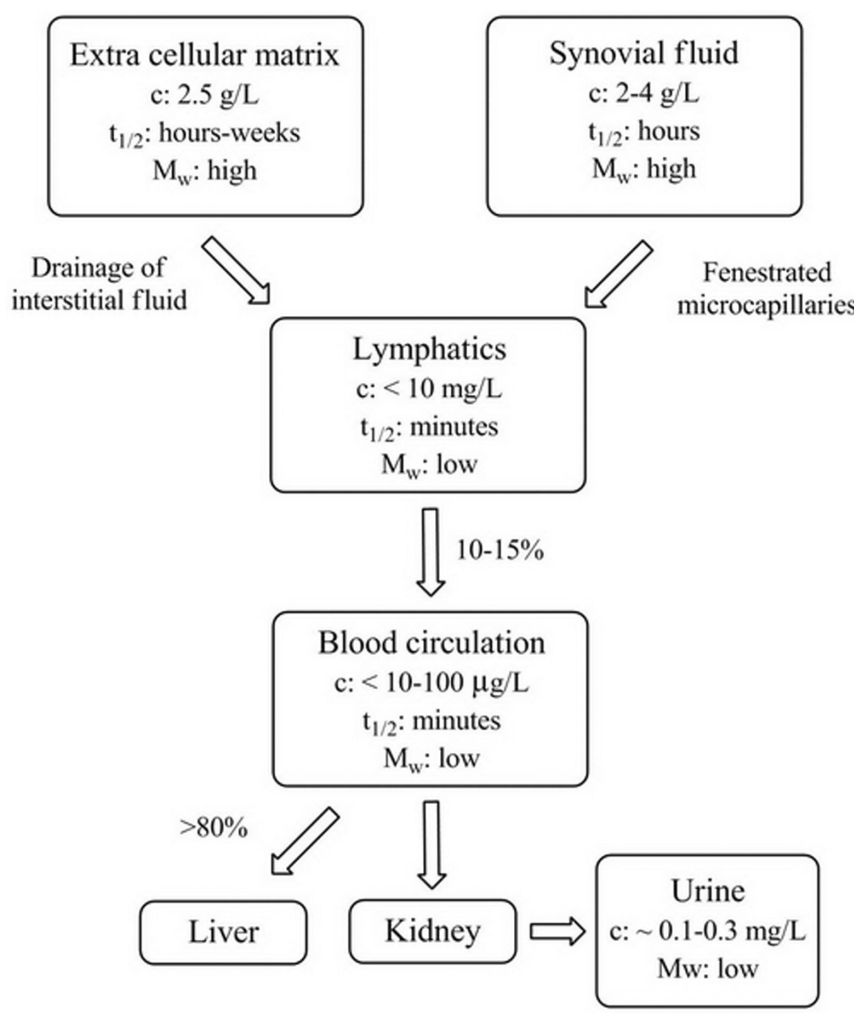

Figure (2).

HA catabolic pathway in the body. Arrows show the flow of HA. Concentration (c), half-life $\left(t_{1 / 2}\right)$, and molecular weight $\left(\mathrm{M}_{\mathrm{w}}\right)$ of HA within the organ systems are indicated. Figure was regenerated with permission [2]. High $\mathrm{Mw}>\sim 1000 \mathrm{kDa}$ and low $\mathrm{Mw}<\sim 450 \mathrm{kDa}$. 
Table (1)

Examples of body tissues/fluids that contain HA. Table was regenerated with permission [92].

\begin{tabular}{c|c|c}
\hline Tissue or body fluid & Concentration $(\mu \mathrm{g} / \mathbf{g} ; \mu \mathrm{g} / \mathbf{m L})$ & Remarks \\
\hline Umbilical cord & 4100 & High molecular weight HA. \\
\hline Joint (synovial) fluid & $1400-3600$ & $\begin{array}{c}\text { Decreasing HA concentration occurs due to increasing the synovial fluid volume } \\
\text { under inflammatory conditions. }\end{array}$ \\
\hline Vitreous body & $140-500$ & During tissue maturation, HA concentration increases. \\
\hline Cartilage & - & HA works as a scaffold for binding other matrix molecules such as aggrecan. \\
\hline Dermis & $200-500$ & HA is used as a "rejuvenating" agent in cosmetic dermatology. \\
\hline Epidermis & 100 & High HA concentration was observed around cells that synthesized dermis. \\
\hline Thoracic lymph & $0.2-50$ & HA molecular weight affects inflammatory response and cell binding. \\
\hline
\end{tabular}


Table (2)

Treatments proposed to enhance age-related changes in skin quality [131].

\begin{tabular}{c|c}
\hline Treatment & Remarks \\
\hline $\begin{array}{c}\text { Skin protections and skin } \\
\text { cares }\end{array}$ & $\begin{array}{c}\text { Sunscreens help to diminish changes in skin quality and appearance caused by sun exposure. Daily skin } \\
\text { care is recommended to improve the quality and appearance of aged skin. }\end{array}$ \\
\hline $\begin{array}{c}\text { Chemical peels } \\
\text { Nonablative therapies }\end{array}$ & $\begin{array}{c}\text { Chemical peels applied directly to the skin use alpha-hydroxy acid, salicylic acid, trichloroacetic acid, or } \\
\text { phenol can improve the appearance of aged skin. } \\
\text { pulsed light, light-emitting diodes, and radiofrequency) are used to improve skin texture, discoloration, and } \\
\text { scarring. }\end{array}$ \\
\hline $\begin{array}{c}\text { Ablative therapies } \\
\text { Botulinum toxin type A }\end{array}$ & $\begin{array}{c}\text { Ablative therapies are laser treatments in which the laser induces ablation of water-containing tissue } \\
\text { (epidermal tissue). }\end{array}$ \\
\hline Dermal fillers & Dermal fillers are used to recover soft-tissue volume of the skin and remove skin wrinkles. \\
\hline
\end{tabular}


Table (3)

Different types of dermal fillers and some of the commercially available products $[3,131,133,137]$.

\begin{tabular}{|c|c|c|c|c|}
\hline Material & Brand name & Description & Duration & Biodegradability \\
\hline Autologous fat & Viable Fat & - & Temporary & Biodegradable \\
\hline \multirow{5}{*}{ Hyaluronic acid } & Restylene ${ }^{\circledR}$ & Crosslinked HA $(20 \mathrm{mg} / \mathrm{mL})$ & Temporary 6-12 months & \multirow{5}{*}{ Biodegradable } \\
\hline & Prelane $\AA$ & Crosslinked HA $(20 \mathrm{mg} / \mathrm{mL})$ & Temporary 6-12 months & \\
\hline & Juvédermm $^{\mathrm{TM}}$ & Crosslinked HA $(24 \mathrm{mg} / \mathrm{mL})$ & Temporary up to 12 months & \\
\hline & Elevess ${ }^{\circledR}$ & Crosslinked HA $(28 \mathrm{mg} / \mathrm{mL})$ & Temporary months & \\
\hline & Hylaform ${ }^{\circledR}$ & Crosslinked HA $(5 \mathrm{mg} / \mathrm{mL})$ & Temporary 3-6 months & \\
\hline \multirow{5}{*}{ Collagen } & Zyderm ${ }^{\circledR}$ & $\begin{array}{l}3.5 \% \text { bovine collagen }+0.3 \% \\
\text { lidocaine }\end{array}$ & Temporary 3-4 months & \multirow{4}{*}{ Biodegradable } \\
\hline & Zyplast ${ }^{\circledR}$ & $\begin{array}{l}3.5 \% \text { crosslinked bovine } \\
\text { collagen }+0.3 \% \text { lidocaine }\end{array}$ & Temporary 3-6 months & \\
\hline & CosmoDerm ${ }^{\circledR}$ & $\begin{array}{l}3.5 \% \text { human collagen }+0.3 \% \\
\text { lidocaine }\end{array}$ & Temporary 3-5 months & \\
\hline & CosmoPlast ${ }^{\circledR}$ & $\begin{array}{l}3.5 \% \text { crosslinked human } \\
\text { collagen }+0.3 \% \text { lidocaine }\end{array}$ & Temporary $3-5$ months & \\
\hline & ArteFill@ & $\begin{array}{l}20 \% \text { PMMA microspheres } \\
+80 \% \text { bovine collagen }(3.5 \%) \\
+0.3 \% \text { lidocaine }\end{array}$ & Permanent & Not biodegradable \\
\hline Calcium hydroxyapatite & Radiessa ${ }^{\circledR}$ & $\begin{array}{l}\text { Calcium hydroxyapatite } \\
\text { microspheres in aqueous gel }\end{array}$ & Semipermanent $2-5$ years & Biodegradable \\
\hline Poly- $L$-lactic acid & Sculptra ${ }^{\circledR}$ & $\begin{array}{l}\text { Injectable PLLA microspheres } \\
\text { suspended in sodium } \\
\text { carboxymethylcellulose gel }\end{array}$ & Semipermanent 18-24 months & Biodegradable \\
\hline $\begin{array}{c}\beta \text {-tricalcium phosphate with } \\
\text { hyaluronic acid }\end{array}$ & Atlean ${ }^{\circledR}$ & - & Semipermanent & Biodegradable \\
\hline \multirow{2}{*}{ Polyacrylamide gel } & Aquamid® & \multirow{2}{*}{-} & \multirow{2}{*}{ Permanent } & \multirow{2}{*}{ Not biodegradable } \\
\hline & Bio-Alcamid $®$ & & & \\
\hline \multirow{5}{*}{ Polymethyl methacrylate } & Arteplast ${ }^{\circledR}$ & \multirow{5}{*}{-} & \multirow{5}{*}{ Semipermanent } & \multirow{5}{*}{ Not biodegradable } \\
\hline & Artecoll® & & & \\
\hline & Artefill ${ }^{\circledR}$ & & & \\
\hline & Dermalive ${ }^{\circledR}$ & & & \\
\hline & Dermadeep® & & & \\
\hline Dimenthylsiloxane polymers & Silicone & - & Permanent & Not biodegradable \\
\hline
\end{tabular}


Table (4)

Properties of healthy synovial fluid and osteoarthritic synovial fluid [105, 144, 145, 150].

\begin{tabular}{|c|c|c|c|c|c|}
\hline & \multirow[b]{2}{*}{$\begin{array}{l}\text { HA molecular } \\
\text { weight (MDa) }\end{array}$} & \multirow[b]{2}{*}{ HA concentration (mg/mL) } & \multicolumn{2}{|c|}{ Viscoelastic properties } & \multirow[b]{2}{*}{$\begin{array}{c}\text { Zero shear } \\
\text { viscosity } \\
\text { (Pa.s) }\end{array}$} \\
\hline & & & $\begin{array}{c}\text { Elastic } \\
\text { modulus }\left(\mathrm{G}^{\prime}\right) \\
(\mathrm{Pa}) \text { at } 2.5 \mathrm{~Hz} \\
\end{array}$ & $\begin{array}{c}\text { Viscous } \\
\text { modulus (G”') } \\
(\mathrm{Pa}) \text { at } 2.5 \mathrm{~Hz} \\
\end{array}$ & \\
\hline Healthy Young Synovial Fluid & $6.3-7.6$ & $2.5-4$ & 23 & 7 & $6-175$ \\
\hline Osteoarthritic Synovial Fluid & $1.6-3.48$ & $1-2$ & 7 & 5 & $0.01-1$ \\
\hline
\end{tabular}


Table (5)

Some of the HA viscosupplements available in the North American market. [141, 144-147]. Adapted data from reference [146] were used with permission.

\begin{tabular}{|c|c|c|c|c|}
\hline Brand name (Generic name) & Molecular weight (kDa) & Approved dosing ${ }^{*}$ & $\begin{array}{c}\text { Amount per } \\
\text { injection } \\
(\mathbf{m L})\end{array}$ & Approved indications \\
\hline $\begin{array}{c}\text { Durolane }{ }^{\circledR}(\text { Hyaluronic } \\
\text { acid, } 2 \%)\end{array}$ & 1000 & 1 injection & 3 & Knee or hip, mild or moderate \\
\hline $\begin{array}{l}\text { Fermathron }{ }^{\circledR}(\text { Sodium } \\
\text { hyaluronate, 1\%) }\end{array}$ & 1000 & $3-5$ injections & 2 & Knee, mild or moderate \\
\hline $\begin{array}{c}\text { Hyalgan }{ }^{\circledR}(\text { Sodium } \\
\text { hyaluronate, } 1 \%)\end{array}$ & $500-730$ & $3-5$ injections & 2 & Knee, shoulder, or hip \\
\hline $\begin{array}{l}\text { NeoVisc } ®(\text { Sodium } \\
\text { hyaluronate, } 1 \%)\end{array}$ & 1000 & $3-5$ injections & 2 & $\begin{array}{l}\text { Synovial fluid replacement following } \\
\text { arthrocentesis }\end{array}$ \\
\hline $\begin{array}{l}\text { Orthovisc } ®(\text { Sodium } \\
\text { hyaluronate, } 1.4 \%)\end{array}$ & $1000-2900$ & 3 injections & 2 & Knee \\
\hline $\begin{array}{l}\text { Ostenil@ }(\text { Sodium } \\
\text { hyaluronate, } 1 \%)\end{array}$ & $1000-2000$ & 3 injections & 2 & $\begin{array}{l}\text { Degenerative or traumatic synovial } \\
\text { joint disorders, including knee joint }\end{array}$ \\
\hline $\begin{array}{l}\text { Supartz@ }(\text { Sodium } \\
\text { hyaluronate, 1\%) }\end{array}$ & $620-1170$ & $3-5$ injections & 2.5 & $\begin{array}{c}\text { Knee nonresponsive to conservative } \\
\text { therapy }\end{array}$ \\
\hline $\begin{array}{l}\text { Suplasyn }{ }^{\circledR}(\text { Sodium } \\
\text { hyaluronate, } 1 \%)\end{array}$ & $500-730$ & $3-6$ injections & 2 & $\begin{array}{l}\text { Synovial fluid replacement following } \\
\text { arthrocentesis }\end{array}$ \\
\hline $\begin{array}{c}\text { Synvisc } ₫(\text { Hylan G-F 20; } \\
\text { Crosslinked HA) }\end{array}$ & $6000-7000$ & 3 injections & 2 & $\begin{array}{l}\text { Knee nonresponsive to } 0.8 \% \\
\text { conservative therapy }\end{array}$ \\
\hline
\end{tabular}

The number of weekly intra-articular injections per treatment course, excluding Durolane $®$, which is given as a single injection. 
Table (6)

Properties of Hyalgan ${ }^{\circledR}$ and Synvisc $®$. Data were adapted from Hyalgan ${ }^{\circledR}$ product information, Orthovisc $®$ product information, Synvisc $®$ product information, and references $[105,144,145]$.

\begin{tabular}{|c|c|c|c|c|c|}
\hline \multirow[b]{2}{*}{ Brand name } & \multirow[b]{2}{*}{ Molecular weight (kDa) } & \multicolumn{2}{|c|}{ Viscoelastic properties } & \multirow[b]{2}{*}{ Number of injections } & \multirow[b]{2}{*}{$\begin{array}{l}\text { Duration of } \\
\text { pain relief }\end{array}$} \\
\hline & & $\begin{array}{c}\text { Elastic } \\
\text { modulus (G') } \\
\text { (Pa) at } 2.5 \mathrm{~Hz}\end{array}$ & $\begin{array}{c}\text { Viscous } \\
\text { modulus (G”) } \\
\text { (Pa) at } 2.5 \mathrm{~Hz}\end{array}$ & & \\
\hline Hyalgan® (Uncrosslinked) & $500-730$ & 0.6 & 3 & $3-5$ & 6 months \\
\hline Orthovisc $®$ (Uncrosslinked) & $1000-2900$ & 60 & 46 & 3 & 6 months \\
\hline Synvisc $®$ (Crosslinked polymer) & $6000-7000$ & $111 \pm 13$ & $25 \pm 2$ & 3 & 6 months \\
\hline
\end{tabular}

